\title{
TINGKAT MANAJEMEN LABA PADA BERBAGAI TAHAP SIKLUS HIDUP PERUSAHAAN DI INDONESIA
}

\author{
Amelia Hartono ${ }^{1}$, Muhammad Hadyan ${ }^{2}$, Rinaningsih Rinaningsih ${ }^{3}$, Retno Yuliati ${ }^{4 *}$ \\ ${ }^{1234}$ Program Studi Akuntansi, Sekolah Bisnis dan Ekonomi, Universitas Prasetiya Mulya, \\ Tangerang \\ *E-mail: retno.yuliati@pmbs.ac.id
}

\begin{tabular}{l} 
Keywords \\
\hline Earning Management, \\
Company Life Cycle, \\
Introduction, Growth, \\
Mature, Shake-out, \\
Decline \\
\hline
\end{tabular}

\section{Article Information}

Received: 2020-05-06

Accepted:

2020-07-03

Available online:

2020-07-20

\begin{abstract}
This research examined the differences in earnings management levels at various company life cycle stages in Indonesia, especially for public companies listed on the Indonesia Stock Exchange from 2002 to 2016. This research uses a sample of 4,400 observational data obtained by purposive sampling from Capital IQ. This research uses Dickinson's (2011) model criteria by dividing the company life cycle into five stages: introduction, growth, mature, shake-out, and decline. This research is tested with the ANOVA model and proves that there is a significant difference in earnings management level in the decline, introduction, and shake-out companies compared to the growth stage. However, the results of this study prove that earnings management value in growth and mature stage companies is not significantly different.
\end{abstract}

\section{PENDAHULUAN}

Pada dasarnya, laporan keuangan disajikan untuk memberikan informasi tentang posisi keuangan, kinerja, dan arus kas perusahaan yang bermanfaat bagi kalangan pengguna laporan dalam membuat keputusan ekonomi (PSAK 1, 2017). Sebagai usaha meningkatkan kredibilitas penyajian laporan keuangan, perusahaan diwajibkan untuk menggunakan basis akrual. Namun, basis akrual memberikan keleluasaan kepada pihak manajemen untuk memilih kebijakan akuntansi selama tidak menyimpang dari PSAK yang berlaku. Pemilihan kebijakan akuntansi tersebut dapat berpotensi mengarah ke praktik manajemen laba, khususnya manajemen laba basis akrual. Tentunya, tindakan ini dapat menimbulkan mislead atau kesalahan persepsi akan kondisi perusahaan oleh para pengguna laporan keuangan (Healy dan Wahlen, 1999).

Dalam beberapa tahun terakhir, pembahasan tentang manajemen laba sering dikaitkan dengan tahap siklus hidup perusahaan (Choi et al, 2016; Mulyasari et al.2016; Zamrudah dan 
Salman, 2013; Madhogarhia et al. 2009). Ketertarikan tersebut diawali dengan adanya keyakinan penggunaan model siklus hidup sebagai salah satu tolak ukur analisis perkembangan perusahaan, seperti prediksi kesempatan dan masalah yang sedang atau akan dihadapi perusahaan (Yazdanfar dan Ohman, 2014). Selain itu, model siklus hidup juga terbukti mampu menggambarkan karakteristik umum perusahaan yang berada di tahap serupa (Anthony dan Ramesh, 1992).

Faktor terpenting dalam pelaksanaan penelitian yang membahas tentang siklus hidup perusahaan adalah metode pengklasifikasian siklus hidup; dimana perusahaan umumnya beroperasi di beberapa jenis industri dan produk. Berdasarkan pertimbangan tersebut, maka Anthony dan Ramesh (1992) membuat metode pengklasifikasian siklus hidup perusahaan yang selanjutnya disempurnakan kembali oleh Dickinson (2011). Metode penggolongan tahap siklus hidup perusahaan dibuktikan lebih sesuai dengan teori ekonomi serta mampu lebih baik menggambarkan kondisi perusahaan (Nagar dan Radhakrishnan, 2015; Mulyasari et al. 2016).

Dengan memodifikasi metode pengklasifikasian siklus hidup perusahaan Anthony dan Ramesh (1992), Madhogarhia et al (2009) melakukan penelitian tentang perbedaan nilai manajemen laba pada tahap growth dan mature. Hasil penelitian tersebut membuktikan bahwa perusahaan tahap growth lebih agresif melakukan manajemen laba dibandingkan pada tahap mature. Hal ini dikarenakan perusahaan pada tahap growth umumnya mempunyai pembelian aset tetap yang lebih banyak untuk kebutuhan investasi, sehingga pihak manajemen memiliki diskresi lebih besar untuk mengelola biaya depresiasi atas aset tetap tersebut (Madhogarhia et al 2009).

Terdapat beberapa penelitian lain yang turut membahas pengaruh siklus hidup perusahaan pada tahap introduction, growth, mature, dan decline terhadap manajemen laba (Mulyasari et al 2016; Chang, 2015; Hastuti, 2011), dimana seluruh penelitian tersebut menghasilkan hubungan yang positif signifikan. Dikarenakan jumlah perolehan laba yang semakin besar dari tahap introduction, growth, hingga mature, sehingga perusahaan akan melakukan manajemen laba untuk menghindari penurunan laba (Kusumawati dan Cahyati, 2014). Selain itu, manajemen laba juga banyak dilakukan untuk mempertahankan atau meningkatkan nilai saham saat perusahaan berada di lingkungan persaingan yang ketat, khususnya pada tahap growth dan mature (Chang, 2015; Mulyasari et al. 2016).

Berbeda dengan hasil tersebut, penelitian Chen (2016) serta Pachariyanon dan Ota (2015) menyatakan bahwa siklus hidup perusahaan memiliki pengaruh negatif signifikan terhadap manajemen laba, khususnya pada tahap growth dan mature. Hal ini dikarenakan perusahaan pada kedua tahap tersebut umumnya memiliki lebih banyak pemegang saham 
yang mengawasi, sehingga tanggung jawab penyampaian informasi akan semakin tinggi; dimana hal ini akan memperkecil peluang manajemen untuk melakukan manajemen laba (Pachariyanon dan Ota, 2015). Selain itu, kemampuan perusahaan dalam mengontrol kinerja keuangan juga semakin baik karena struktur organisasi perusahaan semakin terstruktur (Chen, 2016). Dengan tercapainya stabilitas kinerja perusahaan, maka peluang manajemen untuk menerapkan tindakan manajemen laba pada tahap growth dan mature akan berkurang.

Di sisi lain, terdapat pula penelitian yang menghasilkan pengaruh tidak signifikan antar siklus hidup perusahaan dengan manajemen laba (Hastuti et al. 2017; Zamrudah dan Salman, 2013; Anggraini, 2012). Anggraini (2012) menjelaskan bahwa pengklasifikasian siklus hidup perusahaan yang kurang luas dapat menyebabkan hasil penelitian bersifat tidak signifikan. Hasil serupa juga diperoleh Kusumawati dan Cahyati (2014) saat melibatkan unsur ukuran perusahaan dalam penelitian, dimana dinyatakan bahwa ukuran perusahaan merupakan variabel yang kurang sesuai untuk digunakan karena tindakan manajemen laba terjadi di setiap ukuran perusahaan. Selain itu, dapat juga dikarenakan kesalahan pemilihan metode perhitungan manajemen laba akrual; seperti The Healy Model yang ternyata kurang mampu mengidentifikasi pelaksanaan manajemen laba (Zamrudah dan Salman, 2013). Hastuti et al . (2017) menambahkan, sistem pengendalian internal terbukti mampu memperlemah hubungan siklus hidup perusahaan dengan manajemen laba hingga menjadi tidak signifikan.

Inkonsistensi hasil penelitian tersebut mendorong penulis untuk menyempurnakan penelitian terdahulu tentang manajemen laba dan siklus hidup perusahaan. Sesuai Dechow et al (1995) pengukuran yang paling baik untuk menghitung nilai manajemen laba akrual adalah The Modified Jones Model. Oleh sebab itu, penelitian ini akan menggunakan The Modified Jones Model untuk mengukur nilai manajemen laba akrual perusahaan. Berbeda dengan sebagian besar penelitian sebelumnya terhadap perusahaan di Indonesia yang menggunakan metode pengklasifikasian siklus hidup perusahaan Anthony dan Ramesh (1992), siklus hidup perusahaan dalam penelitian ini akan diidentifikasi berdasarkan metode pengklasifikasian siklus hidup yang telah disempurnakan oleh Dickinson (2011); dimana siklus hidup perusahaan terbagi atas lima tahap yaitu introduction, growth, mature, shake-out, dan decline.

Meski penelitian yang menggunakan metode pengklasifikasian Dickinson (2011) telah dilakukan di Indonesia oleh Kusumawati dan Cahyati (2014), tetapi penelitian tersebut hanya mampu membuktikan bahwa siklus hidup perusahaan dari tahap introduction, growth, mature hingga decline, memiliki pengaruh positif signifikan terhadap manajemen laba namun tidak dapat menunjukkan tingkat perbedaan manajemen laba pada setiap tahap siklus. Penelitian yang membahas tentang tingkat manajemen laba pada setiap tahap siklus hidup perusahaan 
pernah dilakukan di Indonesia (Mulyasari et al. 2016) dan di Amerika (Madhogarhia et al. 2009) juga menggunakan metode pengklasifikasian Anthony dan Ramesh (1992). Sedangkan, penelitian yang menggunakan metode Dickinson (2011) dalam membahas tingkat manajemen laba pada setiap tahap siklus hidup perusahaan dilakukan terhadap sampel perusahaan di Amerika oleh Choi et al (2016). Penelitian ini menggunakan metode Dickinson (2011) untuk menyempurnakan penelitian sebelumnya dalam mengukur tingkat perbedaan manajemen laba pada setiap tahap siklus hidup perusahaan di Indonesia.

\section{PENGEMBANGAN HIPOTESIS}

\section{Manajemen Laba dan Siklus Hidup Perusahaan}

Perusahaan tahap introduction melakukan manajemen laba untuk memperoleh sumber pendanaan eksternal yang selanjutnya dapat digunakan sebagai investasi awal perusahaan (Stice, Stice dan Skousen, 2005). Meski demikian, tingkat manajemen laba yang dilakukan belum terlalu besar karena pihak prinsipal belum berekspektasi tinggi terhadap perolehan laba perusahaan (Zamrudah dan Salman, 2013). Namun, prinsipal mulai mengharapkan nilai pengembalian investasi yang lebih besar pada tahap growth (Yulianti, 2005) dan perusahaan dituntut untuk mempu memenuhi ekspektasi analis (Skinner dan Sloan, 2002); dimana kedua hal ini akan mendorong pelaksanaan manajemen laba. Perusahaan tahap mature melakukan manajemen laba agar perusahaan mampu memenuhi ekspektasi nilai pengembalian investasi yang semakin besar dari pihak prinsipal (Mulyasari et al. 2016). Selanjutnya, manajemen laba dilakukan oleh perusahaan tahap shake-out agar dapat memperbaiki kondisi perusahaan yang sedang terpuruk. Pada tahap terakhir atau decline, tindakan manajemen laba akan cenderung dilakukan untuk memenuhi kepentingan pihak manajemen; dimana pihak manajemen tetap mengharapkan perolehan bonus meski perusahaan sudah tidak kondustif (Zamrudah dan Salman, 2013). Maka, penelitian ini mengajukan hipotesis utama berupa:

\section{H1: Terdapat perbedaan tingkat manajemen laba pada setiap tahap siklus hidup perusahaan.}

Perusahaan yang baru memasuki pasar umumnya memiliki pengetahuan minim atas pasar sehingga belum dapat memaksimalkan potensi laba dan biaya yang seharusnya dikeluarkan (Dickinson, 2011), belum disambut baik oleh pasar (Hanafi dan Halim, 2016), serta memiliki laba yang bernilai negatif akibat pengeluaran investasi awal (Mueller, 1972). Dengan kebutuhan dana yang cukup besar tersebut, maka perusahaan tahap introduction umumnya akan membutuhkan sumber pendanaan eksternal untuk dapat berkembang. Sehingga, tindakan manajemen laba dilakukan agar perusahaan mampu memperoleh 
pendanaan dari pihak eksternal (Stice et al. 2005). Meski demikian, perusahaan pada tahap ini cenderung dipimpin secara penuh oleh pemilik perusahaan dan belum ada intervensi lain dari pihak manajemen (Miller dan Friesen, 1984). Dengan demikian, kinerja perusahaan cenderung sesuai dengan ekspektasi pemilik perusahaan. Oleh sebab itu, maka pelaksanaan manajemen laba pada tahap introduction diasumsikan belum berdampak besar bagi perusahaan mengingat pemegang saham tidak menuntut banyak pada tahap ini (Zamrudah dan Salman, 2013).

Seiring berjalannya waktu, perusahaan mulai diterima oleh konsumen dan memiliki peningkatan permintaan produk perusahaan secara signifikan. Kondisi perusahaan tersebut sangat identik dengan karakter perusahaan pada tahap growth, dimana semakin diperjelas dengan pergerakan arus kas perusahaan dari hasil penjualan yang meningkat (Hanafi dan Halim, 2016). Meski demikian, perolehan laba belum besar (Zamrudah dan Salman, 2013).

Pada tahap ini pula, tanggung jawab kegiatan operasional mulai dialihkan ke pihak manajemen dan konflik keagenan mulai muncul (Miller dan Friesen, 1984). Mengingat kegiatan operasional semakin baik serta unsur ketidakpastian perusahaan juga mulai berkurang (Mueller, 1972), maka pemilik perusahaan akan mengharapkan nilai pengembalian investasi yang lebih tinggi dari perusahaan. Selain itu, nilai perusahaan akan berkurang secara signifikan apabila terjadi perubahan mendadak terhadap jumlah pendapatan perusahaan. Hal ini dikarenakan investor belum memiliki kepercayaan besar terhadap perusahaan dan mudah curiga hal buruk akan adanya hal buruk yang menimpa perusahaan (Skinner dan Sloan, 2002). Tentunya, hal ini akan mendorong motivasi pihak manajemen untuk semakin melakukan manajemen laba (Yulianti, 2005; Choi et al, 2016; Madhogarhia et al. 2009).

Tahap ketiga yang akan dilalui perusahaan adalah mature, dimana pihak manajemen sudah memiliki kematangan dari segi profesionalisme kerja (Hastuti, 2011) dan beroperasi secara efektif dan efisien (Dickinson, 2011). Hal ini menyebabkan kesulitan bagi pihak manajemen untuk meningkatkan margin laba guna memenuhi ekspektasi timbal balik investasi dari pemegang saham yang meningkat. Meski demikian, perusahaan pada tahap mature memiliki keuntungan tersendiri karena dikenal sebagai perusahaan "glamor" dengan reputasi yang sangat baik. Maka, analis akan cenderung mengurangi sifat praduga saat perusahaan mengalami perubahan mendadak yang tidak signifikan (Mulyasari et al. 2016). Dengan demikian, nilai manajemen laba pada tahap mature cenderung lebih kecil dibandingkan tahap sebelumnya (Choi et al, 2016; Chen, 2016; Mulyasari et al. 2016; Zamrudah dan Salman, 2013). 
Pada tahap berikutnya, yang dikenal dengan tahap shake-out, perusahaan mulai mengalami penurunan kinerja akibat meningkatnya jumlah kompetitor di industri serupa yang turut mengadopsi strategi keberhasilan perusahaan (Mueller, 1972). Hal ini ditunjukkan melalui rendahnya tingkat pertumbuhan penjualan, tidak ada pengeluaran modal secara besar, serta sebagian besar perolehan laba perusahaan tidak dialokasikan untuk pengembangan perusahaan (Anthony dan Ramesh, 1992). Dengan kondisi perusahaan yang sedang terpuruk, maka pihak manajemen akan cenderung meningkatkan frekuensi manajemen laba untuk tetap mampu memenuhi ekspektasi pemegang saham dan memperoleh bonus yang diinginkan.

Kondisi perusahaan yang semakin tidak stabil dan kondusif mendorong munculnya berbagai kontroversi antar pihak manajemen untuk mampu mempertahankan perusahaan (Miller dan Friesen, 1984). Apabila perusahaan tidak mampu melakukan inovasi kembali dan mengembalikan posisi perusahaan ke tahap awal siklus hidup, maka kinerja perusahaan senantiasa menurun dan mencapai titik puncaknya pada tahap decline (Adizes, 1979). Tentunya, penurunan kinerja ini akan memengaruhi jumlah bonus yang akan diterima pihak manajemen. Ditambah dengan adanya tuntutan dari pemegang saham perusahaan untuk tetap mampu menyajikan laporan keuangan dengan kinerja yang baik, maka pihak manajemen akan berusaha mempertahankan citra baik perusahaan melalui pelaksanaan manajemen laba (Zamrudah dan Salman, 2013). Selain itu, perusahaan pada tahap decline umumnya akan menghadapi banyak kontroversi antar anggota perusahaan serta kurangnya ketaatan anggota perusahaan terhadap regulasi yang berlaku; dimana hal ini akan meningkatkan peluang terjadinya praktik manajemen laba (Chen, 2016).

H1a. Terdapat perbedaan tingkat manajemen laba pada siklus hidup perusahaan tahap introduction dan growth.

$H_{1}$ b. Terdapat perbedaan tingkat manajemen laba pada siklus hidup perusahaan tahap mature dan growth.

H1c. Terdapat perbedaan tingkat manajemen laba pada siklus hidup perusahaan tahap shake-out dan growth.

$H_{1}$ d. Terdapat perbedaan tingkat manajemen laba pada siklus hidup perusahaan tahap decline dan growth

\section{METODE PENELITIAN}

Penelitian ini dilakukan melalui serangkaian tahap atau metode penelitian. Berikut merupakan penggambaran metode penelitian secara rinci:

\section{Populasi dan Sampel}

Penelitian ini memanfaatkan data sekunder seluruh perusahaan terdaftar di Bursa Efek Indonesia dalam periode tahun 2002 hingga tahun 2016. Proses pemilihan sampel dilakukan 
secara purposive sampling dari data Capital IQ dengan mempertimbangkan beberapa kriteria sampel. Berikut adalah tabel daftar perolehan sampel penelitian:

Tabel 2

Perolehan Sampel Penelitian

\begin{tabular}{lc}
\hline \multicolumn{1}{c}{ Kriteria Pemilihan Sampel } & $\begin{array}{c}\text { Jumlah } \\
\text { Perusahaan }\end{array}$ \\
\hline $\begin{array}{l}\text { Perusahaan terbuka yang terdaftar di Bursa Efek Indonesia sejak tahun 2002 } \\
\text { hingga 2016 }\end{array}$ & 8.505 \\
Perusahaan keuangan & $(1.455)$ \\
Perusahaan yang memiliki arus kas bernilai nol & $(1.598)$ \\
Perusahaan dengan laporan keuangan yang tidak lengkap & $(1.052)$ \\
Jumlah akhir data sampel penelitian & 4.400 \\
\hline
\end{tabular}

Sumber: Bursa Efek Indonesia

\section{Operasionalisasi Variabel}

Penelitian ini memiliki variabel independen berupa lima tahap siklus hidup perusahaan berdasarkan model Dickinson (2011), yaitu introduction, growth, mature, shake-out, dan decline. Sedangkan, variabel dependen dalam penelitian ini adalah manajemen laba akrual yang dihitung menggunakan The Modified Jones Model (Dechow, Sloan, dan Sweeney, 1995).

\section{Variabel Dependen}

Sesuai dengan modifikasi model perhitungan manajemen laba akrual yang dilakukan oleh Dechow et al. (1995) yang disebut sebagai The Modified Jones Model, dijelaskan bahwa perusahaan yang tidak melakukan manajemen laba akan memiliki nilai total akrual (pengurangan laba bersih dengan arus kas operasional perusahaan di tahun bersangkutan) yang bernilai sama dengan jumlah akrual nondiskresioner (jumlah pendapatan setelah dikurangi piutang serta biaya kotor tanah, bangunan dan peralatan perusahaan). Apabila nilai total akrual dengan akrual nondiskresioner perusahaan berbeda, maka perusahaan tersebut telah melakukan tindakan manajemen laba. Selanjutnya, selisih dari total akrual dengan jumlah akrual nondiskresioner perusahaan tersebut akan disebut sebagai nilai eror atau akrual diskresioner perusahaan yang menunjukkan nilai manajamen laba perusahaan. Model perhitungan manajemen laba akrual perusahaan dinyatakan sebagai:

TAC $_{i t} /$ TA $_{i t-1}=\alpha_{1}(1 /$ TAAt-1 $)+\alpha_{2}\left\{\left(\Delta\right.\right.$ REV $_{i t}-\Delta$ REC $\left._{i t}\right) /$ TA $\left._{i t-1}\right\}+\alpha_{3}\left(\right.$ PPE $_{i t} /$ TAit-1 $)+\mathrm{e}_{i t}$

Selanjutnya, seluruh nilai manajemen laba akrual yang bersifat negatif akan diabsolutkan atau dianggap bernilai positif. Hal ini dikarenakan penelitian ini hanya membahas tingkat manajemen laba akrual yang terjadi, namun tidak menjelaskan bentuk manajemen laba yang meningkatkan atau menurunkan laba.

\section{Variabel Independen}

Variabel independen dalam penelitian ini adalah siklus hidup perusahaan yang terbagi 
atas lima tahap, yaitu introduction, growth, mature, shake-out, dan decline. Perusahaan tahap introduction umumnya baru memasuki pasar dengan sedikit informasi tentang potensi pendapatan dan biaya yang dapat diperoleh perusahaan, melakukan investasi dalam jumlah besar, dan memiliki utang yang lebih tinggi daripada modal.

Pada tahap growth, perusahaan mulai mampu memperoleh laba dari aktivitas operasi, cenderung melakukan ekspansi, serta memiliki tingkat kebutuhan pendanaan eksternal yang tinggi. Pada tahap mature, perusahaan sudah memiliki efektivitas dan efisiensi kinerja yang maksimal sehingga memperoleh laba dan arus kas yang cukup untuk melakukan investasi di seluruh kegiatan yang tersedia. Memasuki tahap shake-out, perusahaan akan mengalami perlambatan pertumbuhan kinerja bahkan penurunan harga dan melakukan likuidasi aset operasional perusahaan.

Pada tahap decline, perusahaan tetap mampu menghasilkan laba namun memiliki tingkat penjualan yang menurun dan perusahaan cenderung fokus untuk melunasi atau melakukan negosiasi ulang atas utang yang dimiliki. Sesuai dengan penggambaran kondisi perusahaan pada setiap tahap siklus, maka Dickinson (2011) mampu memetakan metode pengklasifikasian siklus hidup perusahaan berdasarkan bentuk arus kas, yaitu:

\section{Tabel 3}

Pola Arus Kas di Setiap Tahap Siklus Hidup Perusahaan

\begin{tabular}{|c|c|c|c|c|c|c|c|c|}
\hline Predicted Sign & $\begin{array}{c}1 \\
\text { Intro- } \\
\text { duction }\end{array}$ & $\stackrel{2}{\text { Growth }}$ & $\begin{array}{c}3 \\
\text { Mature }\end{array}$ & $\begin{array}{c}4 \\
\text { Shake- } \\
\text { Out }\end{array}$ & $\begin{array}{c}5 \\
\text { Shake- } \\
\text { Out }\end{array}$ & $\begin{array}{c}6 \\
\text { Shake- } \\
\text { Out }\end{array}$ & $\begin{array}{c}7 \\
\text { Decline }\end{array}$ & $\begin{array}{c}8 \\
\text { Decline }\end{array}$ \\
\hline $\begin{array}{l}\text { Cash flows from } \\
\text { operating activities }\end{array}$ & - & + & + & - & + & + & - & - \\
\hline $\begin{array}{l}\text { Cash flows from } \\
\text { investing activities }\end{array}$ & - & - & - & - & + & + & + & + \\
\hline $\begin{array}{l}\text { Cash flows from } \\
\text { financing activites }\end{array}$ & + & + & - & - & + & - & + & - \\
\hline
\end{tabular}

Sumber: Dickinson (2011)

Dikarenakan tahap growth diteliti oleh seluruh penelitian terdahulu yang membahas tentang manajemen laba dan siklus hidup perusahaan, maka tahap growth ditetapkan sebagai dasar pembanding dalam model ANOVA. Variabel siklus hidup perusahaan mengandung unsur kualitatif, sehingga variabel ini akan diklasifikasian secara skala nominal menggunakan dummy.

\section{Metode Analisis}

Penelitian ini akan menguji data panel seluruh perusahaan non finansial yang terdaftar di Bursa Efek Indonesia selama tahun 2002 hingga 2016 menggunakan program STATA 13, 
dimana model penelitian memiliki variabel dengan skala rasio (regressor) dengan skala nominal (regressand). Sesuai dengan Gujarati dan Porter (2009), salah satu model penelitian yang dapat digunakan adalah ANOVA. Dikarenakan seluruh data variabel independen bersifat nonparametrik atau dummy, sehingga uji asumsi klasik tidak perlu dilakukan (Gujarati dan Porter, 2009).

Berikut merupakan model penelitian yang digunakan:

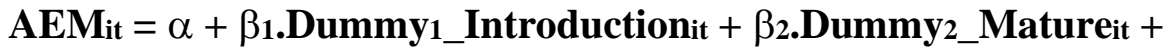 $\beta 3 . D u m m y 3 \_S h a k e o u t i t+\beta$ 4.Dummy4_Decline $i t$}
$\mathrm{AEM}_{\mathrm{it}}$
: nilai manajemen laba akrual perusahaan i pada tahun $\mathrm{t}$
$\alpha$
: koefisien nilai manajemen laba akrual di tahap growth
$\beta_{1}, \beta_{2}, \beta_{3}, \beta_{4}$
: koefisien beda nilai manajemen laba akrual dengan $\alpha$

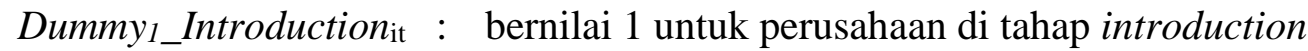
bernilai 0 untuk perusahaan di tahap lain

Dummy2_Mature $_{\text {it }} \quad$ : bernilai 1 untuk perusahaan di tahap mature bernilai 0 untuk perusahaan di tahap lain

Dummy3_Shakeout $t_{\mathrm{it}} \quad$ : bernilai 1 untuk perusahaan di tahap shake-out bernilai 0 untuk perusahaan di tahap lain

Dummy4_Decline $_{\mathrm{it}} \quad$ : bernilai 1 untuk perusahaan di tahap decline bernilai 0 untuk perusahaan di tahap lain

Sebelum memulai seluruh rangkaian penelitian, pengumpulan data sampel akan dilakukan sesuai dengan kriteria sampel yang telah ditentukan. Selanjutnya, penulis melakukan pemilahan perusahaan sesuai pengklasifikasian siklus hidup perusahaan model Dickinson (2011) secara manual. Setelah tahap siklus hidup setiap perusahaan sudah teridentifikasi, nilai manajemen laba untuk setiap perusahaan akan dihitung menggunakan The Modified Jones Model. Hasil statistik deskriptif mampu menunjukkan perbedaan tingkat manajemen laba secara rata-rata untuk setiap tahap siklus perusahaan.

Perbedaan nilai secara rata-rata yang telah ditunjukkan dalam statistik deskriptif akan diuji menggunakan model ANOVA untuk mengetahui apakah nilai tersebut memiliki perbedaan secara signifikan. Apabila nilai probabilitas (nilai $\mathrm{P}>|\mathrm{t}|$ ) lebih kecil atau sama dengan 0,05, maka dapat dinyatakan bahwa nilai manajemen laba tersebut memiliki perbedaan signifikan sebesar koefisien dengan tahap base. Tahap ini juga turut menguji signifikansi dan besaran pengaruh seluruh variabel independen terhadap variabel dependennya; dimana apabila nilai probabilitas (atau nilai Prob > F) kurang dari atau sama 
dengan 0,05, maka dapat dinyatakan bahwa variabel independen memiliki pengaruh signifikan terhadap variabel dependen penelitian. Sesuai dengan penelitian terdahulu yang menguji perbedaan tingkat manajemen laba dengan siklus hidup perusahaan (Choi et al. 2016; Madhogarhia et al. 2009) serta Gujarati dan Porter (2009), besaran pengaruh variabel independen terhadap variabel dependen bernilai kurang dari $10 \%$.

\section{HASIL PENELITIAN DAN PEMBAHASAN}

\section{Statistik Deskriptif}

Berikut merupakan tabel penggambaran umum dari nilai rata-rata, standar deviasi, minimum, dan maksimum dari tingkat manajemen laba pada setiap tahap siklus hidup perusahaan:

\section{Tabel 4}

Statistik Deskriptif - Manajemen Laba Akrual

\begin{tabular}{cccccc} 
& \multicolumn{5}{c}{ AEM } \\
\cline { 2 - 6 } Tahap Siklus & Obs. & Mean & $\begin{array}{c}\text { Std. } \\
\text { Deviasi }\end{array}$ & Min & Max \\
\hline Introduction & 721 & 0,1247 & 0,13 & 0,0000024 & 0,9088 \\
Growth & 1.137 & 0,0812 & 0,09 & 0,0000017 & 0,7702 \\
Mature & 1.798 & 0,0823 & 0,10 & 0,0001295 & 0,9945 \\
Shake-Out & 480 & 0,0913 & 0,11 & 0,0000371 & 0,9124 \\
Decline & 264 & 0,1254 & 0,16 & 0,0000555 & 0,9129 \\
\hline
\end{tabular}

Keterangan:

AEM : manajemen laba akrual

Mean: nilai rata-rata

Min : nilai minimum

Obs. : jumlah observasi

Std. Deviasi : nilai standar deviasi

Max : nilai maksimum

Berdasarkan penjelasan tersebut, diketahui bahwa tingkat manajemen laba dari urutan tertinggi hingga terendah berada pada perusahaan di tahap decline, introduction, shake-out, mature, dan growth secara berurutan. Namun, perbedaan nilai secara rata-rata ini harus diuji lebih lanjut pada bagian berikutnya untuk memastikan apakah tingkat manajemen laba antar tahap siklus berbeda secara signifikan.

Secara lebih rinci, kondisi perusahaan di Indonesia per tahap siklus hidup mampu tergambar dari Tabel 5 berikut: 


\section{Tabel 5}

\section{Statistik Deskriptif-Arus Kas}

\begin{tabular}{llllll}
\hline & & \multicolumn{4}{c}{ Mean } \\
\cline { 3 - 6 } & & \multicolumn{1}{c}{ Obs. } & \multicolumn{1}{c}{ CFO } & \multicolumn{1}{c}{ CFI } & \multicolumn{1}{c}{ CFF } \\
\hline Introduction & & 721 & $-147.695,266$ & $-235.613,47$ & $416.842,41$ \\
Growth & 1.137 & $326.573,68$ & $-603.410,92$ & $395.108,90$ \\
Mature & & 1.798 & $731.415,72$ & $-377.230,52$ & $-318.168,92$ \\
& & 108 & $-43.765,75$ & $-63.816,81$ & $-55.397,44$ \\
Shake-Out & I & 44 & $47.732,89$ & $37.656,92$ & $138.205,44$ \\
& II & 328 & $133.934,99$ & $109.574,99$ & $-203.782,49$ \\
Decline & III & 131 & $-103.374,44$ & $42.192,96$ & $89.537,72$ \\
& I & 133 & $-42.324,00$ & $95.872,66$ & $-62.222,39$ \\
\hline
\end{tabular}

Keterangan:

Obs. : : jumlah observasi

CFI : arus kas dari aktivitas investasi

CFO : arus kas dari aktivitas operasi CFF : arus kas dari aktivitas pendanaan

Secara garis besar, terlihat bahwa perusahaan non finansial di Indonesia umumnya memiliki kondisi perusahaan terlihat kurang baik saat memasuki tahap shake-out dan decline. Hal ini terlihat dari jumlah perusahaan tahap shake-out dan decline di Indonesia yang paling banyak diklasifikasikan ke tahap siklus hidup Dickinson (2011) kategori III dan II secara berurutan; dimana penggabungan kedua tahap ini mengidentifikasikan perusahaan yang sedang terikat utang serta tidak mampu mengoptimalkan sisa pendanaan untuk mengembalikan kondisi perusahaan.

\section{Pengujian Hipotesis}

Dengan menggunakan jumlah sampel penelitian sebesar 4.400 data, model penelitian ini mampu menghasilkan nilai Prob > F sebesar 0,000 atau lebih kecil dari 0,05. Hal ini menunjukkan bahwa variabel siklus hidup secara bersama-sama memiliki pengaruh signifikan terhadap nilai manajemen laba perusahaan.

\section{Tabel 6}

\section{Hasil Pengujian Hipotesis}

\begin{tabular}{lcc}
\hline & Coef. & p-value \\
\hline Introduction & 0,0435198 & $0,000^{* * *}$ \\
Mature & 0,0010743 & 0,797 \\
Shake-Out & 0,0101005 & $0,093^{*}$ \\
Decline & 0,0442165 & $0,000^{* * *}$ \\
Konstanta & 0,0811895 & $0,000^{* * *}$ \\
F-stat & & 0,0000 \\
Adj. $\mathrm{R}^{2}$ & 0,0241 \\
$* * *$ signifikan pada $\alpha=1 \%, * *$ signifikan pada $\alpha=5 \%, *$ signifikan pada $\alpha=1 \%$
\end{tabular}

Keterangan:

Coef. : koefisien 
F-stat : nilai signifikansi model

$p$-value : nilai signifikansi variabel

Adj. $\mathrm{R}^{2}$ : besaran pengaruh variabel independen terhadap variabel dependen

Sesuai dengan tabel tersebut, maka model penelitian dapat ditulis menjadi:

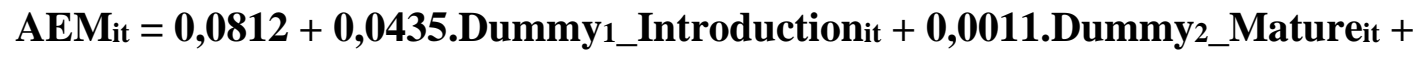 0,0101.Dummy3_Shakeoutit+ 0,0442.Dummy4_Declineit}

Gambaran hasil pengujian diatas menunjukkan bahwa tahap growth - yang merupakan base dari penggunaan model ANOVA, memiliki nilai manajemen laba sebesar 0,0812. Tahap introduction dan tahap decline memiliki perbedaan signifikan (di tingkat 1\%) sebesar 0,0442 dan 0,0435 dari tahap growth; atau dapat dinyatakan bahwa nilai manajemen laba tahap introduction dan decline sebesar 0,1247 dan 0,1254 secara berurutan.

Nilai manajemen laba antar tahap growth dan shake-out juga berbeda 0,0101 dan signifikan pada tingkat 10\%; atau dapat dinyatakan tingkat manajemen laba pada tahap shakeout senilai 0,0913. Namun, tingkat manajemen laba pada siklus hidup perusahaan tahap growth dan mature tidak berbeda secara signifikan karena memiliki nilai probabilitas lebih besar dari 0,01, 0,05, maupun 0,10 .

\section{Analisis dan Diskusi}

Penelitian ini menetapkan tahap growth sebagai dasar pembanding untuk pengujian hipotesis dengan model ANOVA. Selain dikarenakan tahap growth diteliti oleh seluruh penelitian terdahulu yang membahas tentang manajemen laba dan siklus hidup perusahaan, ternyata penelitian ini juga mampu membuktikan bahwa tahap growth memiliki tingkat manajemen laba terendah dibandingkan tahap lainnya. Hal ini tentunya memperkuat alasan tahap growth ditetapkan sebagai dasar pembanding dalam model ANOVA.

Dari hasil uji hipotesis pada Tabel 6, maka hipotesis awal penelitian yang menyatakan bahwa terdapat perbedaan tingkat manajemen laba pada setiap tahap siklus perusahaan dapat diterima. Selanjutnya, analisis lebih rinci akan dilakukan untuk mengetahui nilai manajemen perusahaan pada tahap mana yang memiliki perbedaan signifikan dengan tahap growth.

\section{Introduction dan Growth}

Hasil pengujian membuktikan bahwa perusahaan pada tahap introduction memiliki nilai manajemen laba yang lebih tinggi 0,0435 secara signifikan dibandingkan dengan tahap growth, pada $\alpha=1 \%$. Nilai manajemen laba pada tahap introduction merupakan kedua tertinggi setelah tahap decline dari kelima tahap siklus. Sesuai Dickinson (2011), perusahaan pada tahap introduction sedang membutuhkan dana besar untuk investasi awal, namun jumlah 
pendapatan perusahaan sangat minim dan tidak mampu memenuhi kebutuhan tersebut. Oleh sebab itu, perusahaan akan mengajukan peminjaman dana dari pihak eksternal. Dikarenakan kinerja perusahaan merupakan salah satu dasar pertimbangan syarat peminjaman dana (Stice, Stice dan Skousen, 2005), maka manajemen laba akan dilakukan. Berdasarkan hal tersebut, maka dapat dinyatakan bahwa tindakan manajemen laba dilakukan pada tahap introduction untuk memenuhi kepentingan pihak manajemen (agen).

Hasil penelitian ini tidak mendukung Zamrudah dan Salman (2013) yang menyatakan bahwa perusahaan tahap introduction cenderung tidak melakukan manajemen laba karena laba perusahaan diasumsikan wajar bernilai negatif. Namun, penelitian ini mendukung hasil pengujian dari Pachariyanon dan Ota (2015), yaitu tingkat manajemen laba pada tahap introduction bernilai tinggi dan cenderung dilakukan dengan meningkatkan laba perusahaan. Hal ini dilakukan agar lebih dapat menarik perhatian investor melalui kinerja perusahaan yang baik dan mampu menunjukkan potensi keberhasilan perusahaan dikemudian hari (Pachariyanon dan Ota, 2015).

\section{Mature dan Growth}

Penelitian ini membuktikan tidak ada perbedaan signifikan nilai manajemen laba perusahaan pada tahap growth dan mature; dengan nilai $\alpha$ sebesar 0,797 atau lebih besar dari 0,05. Hal ini sesuai dengan penggambaran Dickinson (2011), yaitu adanya kemiripan dari segi perolehan pendapatan untuk perusahaan pada tahap growth dan mature. Jumlah perolehan pendapatan pada kedua tahap ini paling besar dibandingkan tahap lainnya karena nilai arus kas operasional perusahaan yang hanya bernilai positif pada tahap growth dan mature (Dickinson, 2011). Kondisi perusahaan yang optimal tersebut ternyata turut mendorong meningkatnya nilai pengembalian investasi yang diharapkan para pemegang saham (Mueller, 1972). Dengan kata lain, para pemegang saham (prinsipal) menuntut agar pihak manajemen (agen) mampu memperlihatkan kinerja perusahaan yang tetap atau bahkan membaik.

Penelitian ini menunjukkan bahwa nilai manajemen laba perusahaan pada tahap growth dan mature tidak berbeda secara signifikan. Hasil ini menolak penelitian Choi et al (2016) dan Madhogarhia, Sutton, Kohers (2009) yang turut menguji perbedaan nilai manajemen laba pada tahap growth dan mature. Maka, pernyataan banyaknya jumlah analisis yang mengikuti akan mendorong dilakukannya tindakan manajemen laba (Choi et al, 2016) dan jumlah investasi yang lebih besar mampu meningkatkan diskresi perusahaan untuk mengelola depresiasi (Madhogarhia, Sutton, Kohers, 2009) ditolak. Penelitian ini mendukung 
penelitian Kusumawati dan Cahyati (2014) di Indonesia yang menyatakan tidak ada perbedaan signifikan antar nilai manajemen laba pada tahap growth dan mature. Hal ini dikarenakan perusahaan pada tahap growth dan mature memiliki kinerja usaha yang baik dan beroperasi di lingkungan usaha yang serupa, sehingga tingkat manajemen laba yang dilakukan tidak berbeda (Kusumawati dan Cahyati, 2014).

\section{Shake-out dan Growth}

Tingkat manajemen laba perusahaan pada tahap shake-out memiliki nilai yang lebih tinggi 0,0101 secara signifikan dari tahap growth pada $\alpha=10 \%$. Tidak ada penelitian terdahulu yang membahas nilai manajemen laba perusahaan pada tahap shake-out. Meski demikian, penggambaran Dickinson (2011) mampu mendukung alasan tingkat manajemen laba yang cukup tinggi pada perusahaan tahap shake-out. Tahap shake-out identik dengan kondisi perusahaan yang sedang tidak kondusif dan berdampak pada penurunan kinerja perusahaan. Maka, aktivitas peremajaan usaha atau melakukan investasi ke lini usaha lain harus mampu dilakukan untuk memulihkan kondisi perusahaan. Dickinson (2011) turut menggambarkan kondisi arus kas pendanaan perusahaan yang membutuhkan bantuan dari pihak eskternal, dimana hal ini menunjukkan besarnya jumlah dana yang harus dimiliki perusahaan untuk melakukan kedua alternatif pemulihan usaha tersebut. Dengan demikian, maka tindakan manajemen laba dilakukan pada tahap shake-out untuk memenuhi kepentingan pihak manajemen (agen), khususnya dalam memperoleh pendanaan eksternal guna mengembalikan kondisi perusahaan.

Selain itu, penggunaan model pengklasifikasian siklus hidup Dickinson (2011) juga mampu memberikan penggambaran lebih jelas mengenai kondisi perusahaan di Indonesia pada tahun 2002 hingga 2016. Perusahaan pada tahap shake-out kategori I dan II akan menggunakan sumber pendanaan eksternal untuk melakukan peremajaan usaha maupun investasi ke lini usaha lain, namun shake-out kategori III menunjukkan perusahaan yang sudah tidak lagi melakukan peremajaan maupun investasi usaha melainkan fokus pada pelunasan utang (Dickinson, 2011). Dari total 480 data observasi perusahaan yang berada pada tahap shake-out, terdapat $68 \%$ perusahaan yang masuk ke tahap shake-out kategori III. Hal ini menunjukkan bahwa perusahaan di Indonesia yang berada pada tahap shake-out sedang memiliki kesulitan untuk memenuhi tuntutan pelunasan utangnya.

\section{Decline dan Growth}

Penelitian ini berhasil membuktikan tingkat manajemen laba tertinggi dilakukan oleh perusahaan tahap decline; dengan nilai yang lebih tinggi 0,0442 dari tahap growth pada $\alpha=$ 
1\%. Hasil ini selaras dengan sebagian besar penelitian terdahulu yang turut menguji nilai manajemen laba pada tahap decline. Perusahaan tahap decline memiliki kondisi internal yang sangat tidak kondusif (Dickinson, 2011) sehingga memunculkan berbagai kontroversi antar manajemen, ketidak-valid-an regulasi perusahaan (Miller dan Friesen, 1984), serta pengendalian internal yang buruk (Chen, 2016). Namun di sisi lain, pihak manajemen harus mampu menunjukkan kondisi perusahaan yang baik agar tetap memperoleh bonus tahunan (Zamrudah dan Salman, 2013). Sehingga, tindakan manajemen laba yang dilakukan pada tahap decline cenderung tinggi untuk kepentingan pihak manajemen (agen), yaitu menghindari penurunan laba (Mulyasari, Sughiri, Herdayinta, 2016), mempertahankan investor (Widyaningrum dan Restuti, 2015), serta mempertahankan nilai saham (Chang, 2015).

Penggambaran perusahaan berdasarkan Dickinson (2011) juga mampu menunjukkan kondisi perusahaan di tahap decline. Dickinson (2011) membagi tahap decline menjadi dua kategori dengan perbedaan utama dari segi tujuan penggunaan dana. Perusahaan tahap decline kategori I menggunakan pendanaan eksternal untuk mengembalikan kondisi perusahaan, sedangkan kategori II identik dengan perusahaan yang memiliki sisa pendanaan namun tidak mampu mengoptimalkan penggunaannya untuk mengembalikan kondisi perusahaan (Dickinson, 2011). Jumlah perusahaan di Indonesia yang diteliti dan memasuki tahap decline sebanyak 264 data observasi, namun 50\% dari jumlah tersebut berada pada tahap decline kategori II. Hal ini menunjukkan kondisi perusahaan di Indonesia pada tahap decline yang ternyata tidak mampu mengoptimalkan sisa pendanaan untuk mengembalikan kondisi perusahaan.

Berdasarkan serangkaian analisis diatas, maka dapat diketahui bahwa tingkat manajemen laba perusahaan tertinggi dilakukan berada pada tahap decline, lalu introduction, dan shake-out. Namun, tidak ada perbedaan signifikan untuk nilai manajemen laba perusahaan pada tahap growth dan mature.

\section{SIMPULAN}

Penelitian ini dilakukan dengan tujuan untuk menganalisis perbedaan tingkat manajemen laba pada setiap tahap siklus hidup perusahaan di Indonesia. Hasil penelitian ini membuktikan adanya perbedaan signifikan pada tingkat manajemen laba di siklus hidup perusahaan tahap introduction, shake-out, dan decline. Nilai manajemen laba tertinggi dilakukan oleh perusahaan tahap decline akibat performa perusahaan yang sangat menurun (Dickinson, 2011) namun pihak manajemen tetap berusaha menyajikan laporan keuangan 
yang baik untuk memperoleh bonus tahunan (Zamrudah dan Salman, 2013). Nilai manajemen laba kedua tertinggi dilakukan oleh perusahaan pada tahap introduction untuk menarik perhatian investor (Pachariyanon \& Ota, 2015). Sedangkan, tingginya nilai manajemen laba juga dilakukan oleh perusahaan tahap shake-out untuk mengembalikan kondisi perusahaan seperti semula. Namun, penelitian ini menunjukkan tidak ada perbedaan signifikan untuk nilai manajemen laba akrual pada tahap growth dan mature. Hal ini dikarenakan perusahaan pada kedua tahap ini sama-sama memiliki kinerja usaha yang baik dan beroperasi di lingkungan usaha yang serupa (Kusumawati dan Cahyati, 2014).

Bagi investor, penelitian ini mampu menjadi dasar pertimbangan sebelum melakukan investasi, khususnya ke perusahaan baru atau yang berada pada tahap introduction. Hal ini dikarenakan perusahaan tahap introduction melakukan manajemen laba untuk menarik perhatian investor serta memberikan sinyal positif mengenai peluang keberhasilan perusahaan dikemudian hari. Bagi pihak manajemen, penelitian ini mampu memberikan peringatan awal untuk lebih bijak dalam melakukan tindakan manajemen laba agar perusahaan dapat menghadapi tantangan pada tahap shake-out dan decline. Sesuai dengan hasil penelitian, terdapat $68 \%$ dari perusahaan tahap shake-out dan $50 \%$ dari perusahaan tahap decline yang berada pada kategori III dan kategori II secara berurutan. Dickinson (2011) menjelaskan bahwa perusahaan pada kedua tahap tersebut kurang mampu mengoptimalkan pendanaan untuk mengembalikan posisi perusahaan akibat besarnya tuntutan pelunasan utang.

Penelitian ini memiliki beberapa keterbatasan dalam pelaksanaannya. Pertama, rentang tahun penelitian yang sangat luas menyebabkan sebanyak 15\% data dari total observasi menjadi tidak lengkap. Selain itu, rentang penelitian ini juga belum mampu mencakup tahun berdirinya seluruh perusahaan yang diteliti sehingga menyebabkan beberapa perusahaan tidak mengalami kelima tahap siklus hidup. Terlebih, ada beberapa perusahaan yang mengalami perubahan tahap siklus hidup yang tidak berurutan. Kedua, model pengklasifikasian siklus hidup Dickinson (2011) tidak mempertimbangkan jenis industri. Dikarenakan penelitian ini dilakukan terhadap perusahaan dari 8 industri yang berbeda, dimana setiap industri tentu memiliki keunikannya tersendiri, maka hal tersebut berpeluang mempengaruhi penggambaran kondisi perusahaan yang sebenarnya di Indonesia. Dengan demikian, penelitian berikutnya diharapkan mampu menyempurnakan penelitian ini dengan menggunakan model lain dalam mengklasifikasikan siklus hidup perusahaan. 


\section{REFERENSI}

Adizes, I. (1979). Organizational Passages-Diagnosing and Treating Lifecycle Problems of Organizations. Organizational Dynamics, 8 (1), 3-25.

Anggraini, A. R. (2012). Pengaruh Siklus Hidup dan Ukuran Perusahaan Terhadap Manajemen Laba. Jurnal Ilmiah Mahasiswa FEB, 1 (2), 515-545.

Anthony, J. H., \& Ramesh, K. (1992). Association Between Accounting Performance Measures and Stock Prices. Journal of Accounting and Economics, 15, 203-227.

Chang, H. S. (2015). Firm Life Cycle and Detection of Accrual-Based Earnings Manipulation. Urbana, Champaign County, Amerika.

Chen, T. (2016). Internal Control, Life Cycle and Earnings Quality. Open Journal of Business and Management, 4, 301-311.

Choi, J., Choi, W., \& Lee, E. (2016). Corporate Life Cycle and Earnings Benchmarks. Australian Accounting Review , 1-14.

Dechow, P. M., Sloan, R. G., \& Sweeney, A. P. (1995). Detecting Earnings Management. The Accounting Review, 70 (2), 193-225.

Dickinson, V. (2011). Cash Flow Patterns as A Proxy for Firm Life Cycle. The Accounting Review, 86 (6), 1969-1994.

Gort, M., \& Klepper, S. (1982). Time Paths in the Diffusion of Product Innovations. The Economic Journal, 92 (367), 630-653.

Gujarati, D. N., \& Porter, D. C. (2009). Basic Econometrics. Boston: McGraw-Hill Irwin.

Hanafi, M. M., \& Halim, A. (2016). Analisis Laporan Keuangan. Yogyakarta: UPP STIM YKPN.

Hastuti, S. (2011). Titik Kritis Manajemen Laba Pada Perubahan Tahap Life Cycle Perusahaan: Analisis Manajemen Laba Riil dan Manajemen Laba Akrual. Jurnal Akuntansi dan Keuangan Indonesia, 8 (2), 107-122.

Hastuti, T. D., Ghozali, I., \& Yuyetta, E. N. (2017). The Effect of Company Life Cycles on The Accruals Earnings Management with Internal Control System as Moderating Variable. Polish Journal of Management Studies, 15 (1), 66-75.

Healy, P. M., \& Wahlen, J. M. (1999). A Review of The Earnings Management Literature and Its Implications for Standard Setting. Accounting Horizons, 13 (4), 365-383.

Ikatan Akuntan Indonesia. (2017). Standar Akuntansi Keuangan. Jakarta: Salemba Empat.

Kusumawati, E., \& Cahyati, A. D. (2014). Pengaruh Siklus Hidup dan Ukuran Perusahaan Terhadap Earning Management Pada Perusahaan Manufaktur yang Terdaftar di Bursa Efek Indonesia. El-Muhasaba, 5 (1), 53-74. 
Madhogarhia, P., Sutton, N. K., \& Kohers, T. (2009). Earnings Management Practices Among Growth and Value Firms. Applied Financial Economics, 19, 1767-1778.

Miller, D., \& Friesen, P. H. (1984). A Longitudinal Study of the Corporate Life Cycle. Management Science, 30 (10), 1161-1183.

Mueller, D. C. (1972). A Life Cycle Theory of The Firm. The Journal of Industrial Economics, 20 (3), 199-219.

Mulyasari, W., Sugiri, S., \& Herdhayinta, H. (2016). Information Content of Earnings Managements: Implications on Growth and Value Companies. Journal of Accounting and Finance in Emerging Economies, 2 (1), 47-56.

Murthy, D. P., \& Jack, N. (2014). Extended Warranties, Maintenance Service and Lease Contracts. London: Springer Verlag.

Nagar, N., \& Radhakrishnan, S. (2015). Firm Life Cycle and Real-Activity Based Earnings Management. Ahmedabad, Gujarat, India.

Pachariyanon, P., \& Ota, Y. (2015). The Relationship Between Company Life-Cycle and The Choice of Earnings Management. Minato, Tokyo, Jepang.

Skinner, D. J., \& Sloan, R. G. (2002). Earnings Surprises, Growth Expectations, and Stock Returns or Don't Let an Earnings Torpedo Sink Your Portfolio. Review of Accounting Studies , 7, 289-312.

Stice, E., Stice, J., \& Skousen, K. (2005). Intermediate Accounting. Ohio: South-Western Publishing Co.

Widyaningrum, L., \& Restuti, M. D. (2015). Perbedaan Earnings Management Berdasarkan Pada Tahapan Life Cycle Perusahaan yang Terdaftar di BEI. Jurnal Ekonomi dan Bisnis, 18 (3), 91-102.

Yazdanfar, D., \& Ohman, P. (2014). Life Cycle and Performance Among SMEs: Swedish Empirical Evidence. The Journal of Risk Finance, 15 (5), 555-571.

Yulianti. (2005). Kemampuan Beban Pajak Tangguhan Dalam Mendeteksi Manajemen Laba. Jurnal Akuntansi dan Keuangan Indonesia, 2 (1), 107-129.

Zamrudah, R., \& Salman, K. R. (2013). Earnings Management Prediction (A Study of Company's Life Cycle). The Indonesian Accounting Review, 3 (2), 107-120. 